\title{
PENGARUH EFIKASI KENDIRI TERHADAP KUALITI GURU PENDIDIKAN ISLAM SEBAGAI MURABBI: KAJIAN DI SEKOLAH MENENGAH KEBANGSAAN MALAYSIA
}

\section{(THE EFFECT OF SELF EFFICACY ON ISLAMIC EDUCATION TEACHERS' QUALITY IN MALAYSIA SECONDARY SCHOOL)}

\author{
Noornajihan Jaafar \\ Faculty of Quranic and Sunnah Studies, Universiti Sains Islam Malaysia, 71800 \\ Bandar Baru Nilai, Negeri Sembilan, Malaysia \\ *E-mail: noornajihan@usim.edu.my
}

Publication date: 24 December 2019

To cite this article: Noornajihan Jaafar. (2019). Pengaruh efikasi kendiri terhadap kualiti guru pendidikan Islam sebagai murabbi: Kajian di Sekolah Menengah Kebangsaan Malaysia. Asia Pacific Journal of Educators and Education, 34, 65-85. https://doi. org/10.21315/apjee2019.34.4

To link to this article: https://doi.org/10.21315/apjee2019.34.4

\begin{abstract}
One's belief in his ability to do certain task affects the quality of individual work. Thus, this study was designed to examine self-efficacy (SE), the quality of Teacher of Islamic Education (TIE) as murabbi and the relationship between the two variables and also the effect of SE toward TIE quality of murabbi. This study used a quantitative approach and the questionnaire was the main instrument. Multi stage cluster sampling technique was used to determine the sample. The sample size involved in this research were 544 TIE representing a population of 8,562 TIE national secondary school in Peninsular Malaysia. The results showed that SE of TIE were very high $(\min =4.32)$ and TIE quality at an excellent level $(\mathrm{min}=4.32)$. In addition, moderate and positive correlation between SE with TIE quality $(r=0.619)$. The multiple regression analysis step by step (step wise) showed that all four aspects of the TIE SE is a predictor of the TIE quality factor as murabbi accounting for $34.2 \%$ of variance change for TIE quality as murabbi. This study was also seen to have implications on the theory and models used; in addition to policy makers, especially the training section; and to the guide instructional practices of TIE.
\end{abstract}

Keywords: self-efficacy, Teacher of Islamic Education, murabbi

(C) Penerbit Universiti Sains Malaysia, 2019. This work is licensed under the terms of the Creative Commons Attribution (CC BY) (http://creativecommons.org/licenses/by/4.0/). 


\begin{abstract}
Abstrak: Kepercayaan seseorang terhadap kemampuannya untuk melakukan sesuatu tugasan memberi kesan kepada kualiti kerja individu. Lantaran itu, kajian ini bertujuan untuk meninjau tahap efikasi kendiri (EK), tahap kualiti guru Pendidikan Islam (GPI) sebagai murabbi Sekolah Menengah Kebangsaan di Semenanjung Malaysia, hubungan antara dua pemboleh ubah tersebut serta pengaruh EK terhadap kualiti GPI sebagai murabbi. Kajian ini adalah berbentuk tinjauan yang menggunakan pendekatan kuantitatif dan soal selidik merupakan instrumen utama kajian. Teknik pensampelan kelompok atas kelompok digunakan bagi menentukan sampel kajian. Saiz sampel yang terlibat dalam kajian ini adalah seramai 544 orang GPI yang mewakili populasi seramai 8562 orang GPI di Sekolah Menengah Kebangsaan di Semenanjung Malaysia. Dapatan kajian menunjukkan EK GPI dan kualiti GPI sebagi murabbi masing-masing berada pada tahap sangat tinggi $(\min =4.32)$ dan cemerlang $(\min =4.32)$. Analisis Pearson pula menunjukkan terdapatnya korelasi yang sederhana dan positif antara EK dengan kualiti GPI sebagai murabbi $(r=$ 0.619). Manakala secara keseluruhan, keempat-empat pemboleh ubah peramal EK GPI memberi pengaruh sebanyak $34.2 \%(\mathrm{r}=0.585)$ kepada perubahan varians bagi kualiti GPI sebagai murabbi. Kajian ini juga dilihat memberi implikasi kepada teori dan beberapa model yang digunakan; selain kepada penggubal polisi khususnya bahagian latihan; dan kepada panduan amalan pengajaran GPI.
\end{abstract}

Kata kunci: efikasi kendiri, guru Pendidikan Islam, murabbi

\title{
PENGENALAN
}

Peranan guru sebagai nadi dalam memperkukuhkan dan memajukan bidang pendidikan di negara ini tidak dapat disangkal. Peranan guru sebagai agen perubah boleh direalisasikan melalui fungsinya sebagai wadah penyampai ilmu, pencorak minda dan pembentuk sahsiah. Dalam melahirkan generasi akan datang yang tinggi keupayaan kognitifnya, penuh dengan nilai murni dan kuat pegangan ajaran agamanya, maka guru perlu bertindak sebagai penggerak kepada transformasi pendidikan negara (Noornajihan \& Ab. Halim, 2012).

Era globalisasi, dunia tanpa sempadan menyaksikan peranan guru yang makin mencabar. Beban guru semakin berat sehingga menuntut kesabaran serta ketanggungjawaban yang hebat (Abdullah, 2011; Mohd Kamal, 2011). Tidak ketinggalan juga dalam hal ini, Guru Pendidikan Islam(GPI). Malah tanggungjawab GPI dilihat lebih besar kerana gelaran ustaz dan ustazah memikul bersama tugas sebagai pendakwah (Ab. Halim, 2012; Ahmad Kilani, 2005; Asmawati, 2005).

Isu-isu seperti keruntuhan akhlak dalam kalangan remaja menyebabkan guru terpaksa berjuang untuk menggalas amanah yang telah diberi. Guru juga turut berhadapan dengan cabaran ledakan teknologi maklumat. Paparan-paparan di media elektronik mahupun media cetak menjadi tontonan kegemaran remaja pada 
hari ini. Ini sedikit sebanyak mempengaruhi pemikiran, sikap dan tingkah laku remaja.

Kualiti GPI sebagai murabbi harus dihayati oleh para pendidik dalam mendepani ragam murid pada abad ini. Murabbi berasal daripada perkataan rabba yang bermaksud mendidik, mengasuh, membesarkan (Ruhi Ba'albaki, 2004). Murabbi juga merupakan pelaku kepada kata terbitan tarbiyah yang ditakrifkan sebagai perbuatan mendidik, mengasuh, membesarkan, memberi kasih sayang (Ab. Halim, 2006). Beliau juga telah menjelaskan peranan guru murabbi sebagai "peranan guru di dalam bilik darjah untuk menjaga, membesarkan, mencurahkan kasih sayang, mendidik, mengajar, menyubur dan memelihara fitrah murid serta membentuk bakat dan kebolehan yang wujud dalam diri mereka. Guru berperanan merealisasikan pembentukan dan pembangunan murid dari aspek JERI agar dapat melahirkan insan soleh yang berakhlak mulia menurut kaca mata Islam" (Ab. Halim, 2006).

Perkataan tarbiyah boleh dirujuk dalam firman Allah dalam surah al-Isra' ayat 24 yang berbunyi:

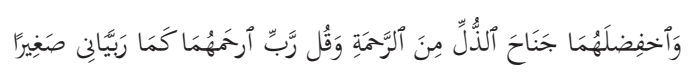

Maksudnya: Dan rendahkan diri mu terhadap mereka berdua dengan penuh kesayangan dan ucapkanlah: "Wahai Tuhanku, kasihilah mereka keduanya, sebagaimana mereka berdua telah mendidik aku waktu kecil" (Abdullah Basmeih, 2010).

Antara ciri-ciri guru Rabbani yang diketengahkan oleh al-Ghazali (n.d.) ialah berperanan seperti ibu bapa atau penjaga kepada murid di sekolah dengan membina hubungan yang ikhlas dengan penuh kasih sayang sehingga timbul kepercayaan antara keduanya. Selain itu guru perlu berusaha menitipkan sifat Rabbani dalam pemikiran dan tindakan pelajar (Surah Ali Imran 3:79) agar pembentukan insan yang cemerlang dunia dan akhirat dapat dilahirkan melalui tarbiyah yang dilakukan oleh guru murabbi.

GPI perlu mempamerkan akhlak terbaik seperti yang ditunjukkan oleh junjungan Nabi SAw (Sofiah, Kamarul Azmi, \& Muhammad Azhar, 2016).

Ini kerana, untuk membentuk generasi Muslim yang holistik dan seimbang dari segi rohani, emosi, intelek dan jasmani, seseorang guru itu bukan sekadar hanya menyampaikan ilmu bahkan turut membimbing para murid. Pembimbing yang 
unggul memerlukan seseorang guru itu menghayati ciri-ciri seorang murabbi iaitu satu pakej kualiti guru yang bersandarkan kepada hadis-hadis Nabi SAW. Ini bersesuaian dengan peranan Nabi SAw yang diutuskan bagi menyempurnakan akhlak manusia, seperti yang dinyatakan dalam hadis yang diriwayatkan oleh alBayhaqi (1988, no. hadis 21301) yang berbunyi:

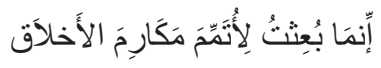

Maksud: "Sesungguhnya, aku (Muhammad SAw) telah diutus untuk menyempurnakan akhlak yang mulia".

Ini bersesuaian dengan matlamat Pendidikan Islam itu sendiri yang antaranya mengangkat martabat al-Quran dan Sunnah sebagai tunjang dalam pembelajaran sepanjang hayat bagi mendapatkan ilmu, kemahiran dan penghayatan (Kamarul Azmi \& Ab. Halim, 2007). Penghayatan kualiti GPI sebagai murabbi yang terzahir melalui amalan seharian GPI memerlukan satu bentuk keyakinan dan kepercayaan diri untuk melakukannya (al-Ghazali, n.d.). Kepercayaan inilah yang dikenali sebagai efikasi kendiri (EK) guru (Bandura, 1997; Gibson \& Dembo, 1984).

\section{REALITI CABARAN GURU PENDIDIKAN ISLAM BERKUALITI MURABBI}

Kajian ini bertitik tolak daripada realiti cabaran yang terpaksa dihadapi, bukan sahaja oleh GPI bahkan hampir semua yang bergelar guru. Bahkan cabaran bagi menyediakan guru yang berkualiti merupakan isu global yang menjadi perhatian pembuat dasar pendidikan bagi setiap negara (Corcoran, 2007; Darling-Hammond, Wei, Andree, Richardson, \& Orphanos, 2009). Namun, tanggungjawab yang lebih berat digalas oleh GPI kerana telah termaktub secara langsung dalam Falsafah Pendidikan Islam (FPI) bahawa GPI bertanggungjawab membentuk murid yang berjaya bukan sahaja di dunia bahkan di akhirat dengan menjadi hamba Allah SWT yang berkemahiran, berkeperibadian tinggi serta mempunyai tasawwur kehidupan yang selari dengan ajaran Islam dan seterusnya bertanggungjawab kepada diri, masyarakat dan alam semesta (Abdullah, 2011).

Pendidikan anak-anak yang pada asalnya berada di bawah naungan keluarga, kini telah diambil alih sebahagian besar tugasnya oleh guru-guru, khususnya GPI dalam mendidik generasi muda (Ab. Halim, 2011). Ini disokong dengan kajian Ab. Halim (2011) yang mendapati bahawa GPI lebih berpengaruh daripada ibu bapa dalam membentuk tahap penghayatan Islam murid dengan nilar $r$ masing- 
masing 0.477 (GPI) dan 0.364 (ibu bapa). Walaupun pada teorinya ibu bapa yang memainkan peranan utama dalam mendidik anak-anak dan guru hanya menyokong di sekolah, tetapi hakikatnya, masa murid lebih banyak di sekolah berbanding di rumah. Persoalannya, mampukah GPI memainkan peranan selaku ibu-bapa di sekolah? (Ab. Halim, 2011).

Kesediaan para guru menghadapi cabaran tanggungjawab serta senario murid masa kini secara tidak langsung dipengaruhi oleh kepercayaan guru terhadap kemampuan serta keupayaan diri dalam melaksanakan tanggungjawab tersebut (Casey, 2011; Coady, Harper, \& De Jong, 2011; Pas, Bradshaw, \& Hershfeldt, 2011). Kepercayaan peribadi inilah yang dikenali sebagai EK (Bandura, 1994; Henson, Bennett, Sienty, \& Chambers, 2000; Ross, 1995). Justeru, tahap EK GPI dalam mendidik murid, secara langsung mempengaruhi amalan dalam pengajaran dan keperibadian GPI. Hal ini seterusnya memberi impak kepada pencapaian akademik dan sahsiah murid (Donna, 2007; Hassan, 1986; 1987).

Kajian-kajian lepas telah menunjukkan bahawa EK merupakan antara elemen penting dalam proses Pengajaran dan Pembelajaran (P\&P) yang mana ia mempengaruhi kualiti seseorang guru (Abu-Tineh, Khasawneh, \& Khalaileh, 2011; Bandura, 1993; Ishak, 2001; Martínez-López, Zagalaz Sánchez, Ramos Álvarez, \& De La Torre Cruz, 2010; Mason, 2010; Rafisah, 2009; Rimm-Kaufman \& Sawyer, 2004; Rorlinda, 2009; Steele, 2010; Weisel \& Dror, 2006; Yoon, 2002) dan amalan pengajarannya (Hartman, 2010; Rimm-Kaufman \& Sawyer, 2004; Settlage, Southerland, Smith, \& Ceglie, 2009; Yılmaz \& Çavaş, 2008). Dalam konteks Malaysia, kajian berkaitan EK guru masih kurang. Berdasarkan kajian yang telah dijalankan, kedapatan beberapa kajian sahaja yang menggunakan EK guru sebagai salah satu pemboleh ubah, antaranya kajian yang telah dijalankan oleh Ishak (2001), Sazali (2004), Khalid et al. (2005), Saaidah (2005), Rahmah (2005), Khalid (2005), Tengku Lung Kui (2006), Rafisah (2009), Rorlinda (2009) dan Noornajihan et al. (2019). Setelah menelusuri kajian-kajian lepas yang berkaitan EK guru (Ishak, 2001; Sazali, 2004; Khalid, 2005; Saaidah, 2005; Rahmah, 2005; Khalid, 2005; Tengku Lung Kui, 2006; Rafisah, 2009; Rorlinda, 2009), pengkaji mendapati bahawa masih belum terdapat kajian mengenai profil EK dalam kalangan GPI dijalankan. Walaupun kajian Noornajihan et al. (2019) berkaitan EK, namun kajian tersebut mengkaji hubungannya dengan peranan GPI sebagai agen perubahan masyarakat.

Kajian mengenai EK guru penting kerana ia dijadikan ukuran dalam menentukan keupayaan seseorang guru dalam pengajaran berkesan (Henson, Kogan, \& VachaHaase, 2001, Yahya, Azah, \& Yaakub, 2006). EK merupakan medium penghubung antara ilmu yang dimiliki dengan tingkah laku pengajaran (Larson, Suzuki, 
Gillespie, Potenza, Bechtel, \& Toulouse, 1992; Khoo \& Tan, 2004; al-Ghazali, n.d.). Menyentuh tentang persoalan yang ditinggalkan dalam perbincangan kajian Ab. Halim et al. (2004) berkenaan isu di mana GPI mengetahui kaedah terbaik dalam pengajaran, namun secara realiti mereka kurang melaksanakannya, pengkaji berpandangan bahawa terdapat kemungkinan EK GPI menjadi punca masalah ini berlaku. Justeru, adalah penting kajian ini dijalankan bagi mengenal pasti tahap EK GPI dan hubungannya terhadap pembentukan kualiti GPI. Objektif kajian ini dijalankan adalah untuk:

1. Mengenal pasti tahap efikasi kendiri guru Pendidikan Islam Sekolah Menengah Kebangsaan (SMK).

2. Mengenal pasti tahap kualiti guru Pendidikan Islam SMK.

3. Menilai hubungan antara efikasi kendiri dengan kualiti guru Pendidikan Islam SMK.

4. Menilai pengaruh efikasi kendiri terhadap kualiti guru Pendidikan Islam SMK.

\section{KEMANTAPAN GURU PENDIDIKAN ISLAM SEBAGAI AGEN SOSIALISASI}

Teori Efikasi Kendiri (EK) pada umumnya mula diperkenalkan oleh Bandura (1977), iaitu kepercayaan peribadi seseorang untuk melaksanakan sesuatu tugasan mengikut piawaian yang telah ditentukan. Kemudiannya teori ini telah dikembangkan oleh Ashton (1984) dan Gibson dan Dembo (1984) dengan memberi fokus kepada EK guru.

EK guru seperti yang diketengahkan oleh Ashton (1984) ialah ukuran keyakinan guru bahawa beliau mempunyai pengaruh ke atas prestasi murid secara keseluruhan, bukan sahaja akademik bahkan pembentukan diri murid. Keyakinan terhadap kekuatan, kebolehan dan keupayaan diri untuk mengajar, membimbing dan mendidik murid inilah yang menjadi faktor yang membezakan antara guru (Gibson \& Dembo, 1984).

Guskey (1987) berpendapat bahawa tahap EK inilah antara pemboleh ubah yang menentukan keberkesanan pengajaran seseorang guru. Ini kerana menurut Ashton (1984), EK guru yang tinggi mempengaruhi usaha, produktiviti dan aktiviti yang dilakukan guru seterusnya membantu pencapaian murid. EK penting bagi guru kerana ia membentuk keterampilan guru (Trentham, Silvern, \& Brogdon, 1985), mempengaruhi penerimaan dan kesediaan guru terhadap sesuatu inovasi 
dan cabaran tugas (Guskey, 1987), membawa kepada peningkatan kerja yang berterusan dan meningkatkan prestasi (Bandura, 1977).

Selain itu, Ashton (1984) berpandangan bahawa EK penting bagi guru kerana ia akan menjadi pendorong untuk guru menjalankan tugas-tugas membimbing dan mendidik yang mana memerlukan kepada ketahanan, kesabaran dan kekreatifan yang tinggi. Guru yang mempunyai EK yang tinggi menurut Ashton (1984) sentiasa berfikiran positif terhadap murid dan akan meletakkan harapan yang tinggi agar murid mereka berjaya. Rasa tanggungjawab yang tinggi membawa kepada gemblengan usaha yang padu; melakukan pelbagai strategik peningkatan kecemerlangan; mengenal pasti masalah dan kelemahan; seterusnya melaksanakan tindakan pemulihan yang bersesuaian bagi memastikan kejayaan muridnya.

Manakala guru yang rendah EK, menurut Ashton (1984), sering berpandangan negatif, melihat kelemahan sebagai suatu halangan yang tidak mampu dibaiki, dan tidak meletakkan apa-apa harapan terhadap murid. Mereka ini kurang rasa tanggungjawab; melihat profesion perguruan hanya sebagai satu laluan kerjaya untuk meneruskan penghidupan; tidak proaktif, sering mencari alasan untuk tidak melaksanakan tugas, tiada impian dalam kerjaya; dan seterusnya meletakkan keupayaan murid, motivasi, sikap dan latar belakang keluarga sebagai punca kegagalan murid. Ini disokong dengan kajian Saklofske, Michayluk dan Rondhawa (1988) yang mendapati terdapatnya hubungan positif antara EK guru dengan tingkah laku mengajar seperti penyampaian, penyoalan dan strategi pengurusan bilik darjah.

Sehubungan itu, GPI yang berperanan sebagai murabbi perlu memiliki EK yang tinggi bagi memastikan tugas mendidik dan membimbing murid berjaya mencapai matlamat seperti yang telah ditetapkan dalam Falsafah Pendidikan Islam (FPI). Ini kerana GPI sebagai murabbi bukan sahaja mengajar, bahkan mempunyai gandaan tugas yang lebih berat iaitu memastikan kejayaan murid dalam akademik, sahsiah mahupun rohani. Tugas ini yang pastinya memerlukan kepada pemikiran yang jelas terhadap matlamat mendidik, ilmu, kemahiran, motivasi, sahsiah terpuji di samping ketahanan, kesungguhan, dinamik serta proaktif; menjadikan EK sebagai pemacu serta pendorong di sebalik komitmen yang besar ini.

Berdasarkan model EK guru Tschannen-Moran, Hoy and Hoy (1998), terdapat tiga dimensi bagi mengukur EK guru, iaitu penglibatan murid, strategi pengajaran dan pengurusan kelas. Namun, merujuk kepada FPI yang mana antara peranan GPI adalah untuk membentuk murid yang cemerlang dunia dan akhirat, maka aspek bimbingan akademik dan sahsiah menjadi salah satu bidang tugas bagi GPI. 
Justeru, pengkaji telah menambah satu lagi dimensi dalam EK GPI, iaitu dimensi keempat, dimensi bimbingan akademik dan sahsiah.

Perbincangan mengenai kualiti GPI pula secara khusus telah dibahaskan oleh Kamarul Azmi (2010) dan Mohd Kassim (2010). Manakala perbincangan mengenai kualiti guru murabbi pula banyak dibahaskan oleh sarjana Islam dalam bidang pendidikan. Ini kerana terminologi murabbi itu sendiri berasal daripada perkataan Bahasa Arab. Terdapat beberapa orang sarjana Islam yang membincangkan tentang kualiti GPI sebagai murabbi dalam penulisan mereka seperti Abdullah Nasih (1968), al-Nahlawi (1979), al-Hammadi (1987) dan al-Hafiz (1988).

Berdasarkan model-model kualiti GPI yang telah dikenal pasti, terdapat sembilan dimensi kualiti GPI yang telah dikenal pasti, iaitu: (1) pemikiran rabbani; (2) penguasaan ilmu agama; (3) pengamalan agama; (4) budaya keilmuan; (5) kemahiran pedagogi; (6) kemahiran psikologi; (7) kemahiran komunikasi; (8) sahsiah dan (9) sumbangan kemasyarakatan.

\section{METODOLOGI KAJIAN}

Kajian ini secara asasnya adalah berbentuk tinjauan (survey) yang dijalankan menerusi kaedah tinjauan deskriptif secara deduktif (Neuman, 2002), iaitu kajian dimulakan dengan pembinaan hipotesis, diikuti dengan pengukuran data kajian secara empirikal dan diakhiri dengan penganalisisan secara kritikal. Jenis tinjauan yang digunakan dalam kajian ini pula ialah tinjauan semasa atau keratan lintang (cross-sectional survey), iaitu data dipungut sekali sahaja daripada suatu sampel pada suatu masa (Creswell, 1998).

Lokasi kajian ini ialah di beberapa buah Sekolah Menengah Kebangsaan (SMK) di bawah seliaan Kementerian Pendidikan Malaysia. Kajian ini melibatkan beberapa buah SMK bagi empat buah negeri, iaitu Kedah, Kelantan, Selangor dan Melaka. Secara amnya, kajian ini menggunakan teknik pensampelan kelompok atas kelompok (multi stage cluster) bagi menentukan sampel kajian. Saiz sampel yang ditentukan dalam kajian ini adalah seramai 544 orang GPI daripada jumlah populasi seramai 8,562 orang GPI.

Data soal selidik telah dianalisis menggunakan perisian Statistical Package for Social Science (SPSS) Versi 20.0. Bagi menjawab soalan kajian dan seterusnya mencapai objektif yang ditetapkan, penganalisisan data kajian ini akan dibahagikan kepada dua bahagian utama, iaitu analisis menggunakan statistik deskriptif dan statistik inferensi. 
Statistik deskriptif digunakan bagi menghuraikan atau membuat ringkasan terhadap data yang diperoleh daripada sampel kajian. Ia merangkumi taburan frekuensi, ukuran kecenderungan tengah (min, mod, media) dan ukuran kebolehubahan (julat, varians, sisihan piawai), selain carta, graf, jadual dan sebagainya sebagai salah satu cara bagi meringkaskan kuantiti data yang besar supaya lebih mudah difahami (Alias, 1996; Azizi, Shahrin, Jamaludin, Yusof, \& Abdul Rahim, 2006).

\section{DAPATAN KAJIAN}

\section{Profil Responden Kajian}

Jadual 1 menunjukkan bahawa jumlah responden GPI lelaki yang terlibat dalam kajian ini adalah seramai 162 orang $(29.8 \%)$ dan responden GPI perempuan pula adalah seramai 382 orang $(70.2 \%)$. Manakala peratusan yang hampir seimbang bagi responden yang bertugas di sekolah bandar (49.8\%) dengan kekerapan seramai 271 orang dan sekolah luar bandar (50.2\%) dengan kekerapan seramai 273 orang. Manakala dari aspek tempoh pengalaman mengajar, seramai 18 orang GPI (3.3\%) telah mengajar antara satu hingga tiga tahun. 32 orang GPI (5.9\%) telah mengajar selama lebih kurang empat hingga enam tahun. Manakala baki responden selebihnya, iaitu seramai 494 orang GPI (90.8\%) telah mengajar lebih daripada tujuh tahun. Kategori kelayakan akademik tertinggi pula, mencatatkan seramai 36 orang responden $(6.6 \%)$ memiliki ijazah sarjana, 489 orang responden (89.9\%) memiliki ijazah sarjana muda, 13 orang responden $(2.4 \%)$ hanya memiliki diploma dan 13 orang responden (1.1\%) memiliki STP/STPM/STAM dan yang setara dengannya.

Jadual 1. Profil responden kajian

\begin{tabular}{lccc}
\hline Kategori & Kumpulan & Kekerapan & Peratus (\%) \\
\hline Jantina & Lelaki & 162 & 29.8 \\
& Perempuan & 382 & 70.2 \\
Lokasi sekolah & Bandar & 271 & 49.8 \\
& Luar bandar & 273 & 50.2 \\
Pengalaman mengajar & $1-3$ tahun & 18 & 3.3 \\
& $4-6$ tahun & 32 & 5.9 \\
& $>7$ tahun & 494 & 90.8 \\
\hline
\end{tabular}


Jadual 1. (sambungan)

\begin{tabular}{lccc}
\hline Kategori & Kumpulan & Kekerapan & Peratus (\%) \\
\hline Kelayakan akademik tertinggi & Ijazah Sarjana & 36 & 6.6 \\
& Ijazah Sarjana Muda & 489 & 89.9 \\
& Diploma & 13 & 2.4 \\
& STP/STPM/STAM/Setara 6 & 6 & 1.1 \\
\hline
\end{tabular}

\section{Tahap Efikasi Kendiri Guru Pendidikan Islam Sekolah Menengah} Kebangsaan

Bagi menjawab soalan kajian 1 (Apakah persepsi GPI SMK terhadap efikasi kendiri mereka?), analisis deskriptif yang meliputi peratusan, kekerapan, min dan sisihan piawai (SP) digunakan. Secara keseluruhan, EK GPI SMK berada pada tahap yang sangat tinggi $(\mathrm{min}=4.32 ; \mathrm{SP}=0.373)$. Namun demikian, jika diteliti dapatan analisis deskriptif mengikut sub konstruk seperti pada Jadual 2, tidak kesemua sub konstruk mencapai skor min sangat tinggi. Ini kerana sub konstruk "bimbingan akademik dan sahsiah" hanya mencapai tahap tinggi $(\min =4.17$; SP $=0.444$ ). Manakala sub konstruk yang lain mencapai tahap sangat tinggi, dengan turutan sub konstruk "penglibatan murid" ( $\min =4.43$; $\mathrm{SP}=0.474)$, diikuti dengan sub konstruk "pengurusan bilik darjah" ( $\min =4.41$; $\mathrm{SP}=0.453)$ dan sub konstruk "strategi pengajaran" $(\min =4.29 ; \mathrm{SP}=0.424)$.

Dapatan ini menunjukkan bahawa, secara keseluruhan, GPI sangat yakin dalam aspek penglibatan murid, pengurusan bilik darjah dan penggunaan strategi pengajaran. Namun, GPI perlu lebih berkeyakinan untuk membimbing murid di bawah jagaan mereka, samada dari aspek akademik mahupun sahsiah. Walau bagaimanapun dapatan ini akan diperincikan dalam bahagian seterusnya dengan melihat skor min bagi setiap item dalam setiap sub konstruk.

Jadual 2. Skor min dan sisihan piawai efikasi kendiri GPI berdasarkan sub konstruk

\begin{tabular}{lcc}
\hline Sub konstruk & Min & Sisihan Piawai \\
\hline Penglibatan murid & 4.43 & 0.474 \\
Pengurusan bilik darjah & 4.41 & 0.453 \\
Strategi pembelajaran & 4.29 & 0.424 \\
Bimbingan akademik dan sahsiah & 4.17 & 0.444 \\
\hline Keseluruhan & 4.32 & 0.373 \\
\hline
\end{tabular}




\section{Tahap Kualiti Guru Pendidikan Islam Sekolah Menengah Kebangsaan}

Bagi menjawab soalan kajian 2 (Apakah persepsi GPI SMK terhadap tahap kualiti mereka?), analisis deskriptif yang meliputi peratusan, kekerapan, min dan sisihan piawai digunakan. Secara keseluruhan, kualiti GPI SMK berada pada tahap cemerlang dengan $\min =4.32 ; \mathrm{SP}=0.373$.

Namun demikian, jika diteliti dapatan analisis deskriptif mengikut sub konstruk seperti pada Jadual 3, tidak kesemua sub konstruk mencapai skor min cemerlang. Ini kerana sub konstruk "kemahiran pedagogi" $(\min =3.58$; $\mathrm{SP}=0.463)$, "sumbangan kemasyarakatan" $(\min =3.72 ; \mathrm{SP}=0.644)$ dan "pengamalan agama" $(\min =4.14 ; \mathrm{SP}=0.436)$ hanya mencapai tahap baik. Manakala sub konstruk yang lain mencapai tahap sangat tinggi, dengan turutan sub konstruk "penguasaan ilmu agama" $(\min =4.98$; $\mathrm{SP}=0.395)$, "pemikiran rabbani" $(\min =4.94$; $\mathrm{SP}=$ 0.246), "kemahiran komunikasi" ( $\min =4.56$; $\mathrm{SP}=0.444)$, "sahsiah" $(\min =4.56$; $\mathrm{SP}=0.387)$, "kemahiran psikologi" ( $\min =4.49 ; \mathrm{SP}=0.424)$, "budaya keilmuan" $(\min =4.37 ; \mathrm{SP}=0.467)$.

Dapatan ini menunjukkan bahawa, secara keseluruhan, GPI cemerlang dalam aspek penguasaan ilmu agama, pemikiran rabbani, kemahiran komunikasi, sahsiah, kemahiran psikologi dan budaya keilmuan. Namun, GPI perlu meningkatkan kualiti mereka dari aspek kemahiran pedagogi, sumbangan kemasyarakatan dan pengamalan agama.

Jadual 3. Skor min dan sisihan piawai kualiti GPI berdasarkan sub konstruk

\begin{tabular}{lcc}
\hline Sub konstruk & Min & Sisihan piawai \\
\hline Pemikiran rabbani & 4.94 & 0.246 \\
Penguasaan ilmu agama & 4.98 & 0.395 \\
Pengamalan agama & 4.14 & 0.436 \\
Budaya keilmuan & 4.37 & 0.467 \\
Kemahiran pedagogi & 3.58 & 0.463 \\
Kemahiran psikologi & 4.49 & 0.424 \\
Kemahiran komunikasi & 4.56 & 0.444 \\
Sahsiah & 4.56 & 0.387 \\
Sumbangan kemasyarakatan & 3.72 & 0.644 \\
Jumlah & 4.32 & 0.373 \\
\hline
\end{tabular}




\section{Hubungan Antara Efikasi Kendiri Dengan Kualiti GPI SMK}

$\mathrm{H}_{\mathrm{o} 1}$ : Tidak terdapat hubungan yang signifikan antara efikasi kendiri dengan kualiti GPI SMK

Hipotesis nol pertama $\left(\mathrm{H}_{\mathrm{ol}}\right)$ yang dibentuk diuji dengan analisis korelasi Pearson bagi melihat hubungan antara EK dengan kualiti GPI. Jadual 4 memaparkan keputusan ujian yang mendapati nilai $r$ ialah 0.619 dan $p=0.000$, iaitu $p<0.01$. Nilai tersebut menunjukkan bahawa hipotesis nol pertama $\left(\mathrm{H}_{\mathrm{ol}}\right)$ berjaya ditolak. Ini menunjukkan bahawa terdapat hubungan sederhana antara EK dengan kualiti GPI SMK (Cohen, 1988; Guilford \& Fruchter, 1978).

Jadual 4. Hubungan di antara Efikasi Kendiri (EK) dengan kualiti Guru Pendidikan Islam (GPI)

\begin{tabular}{lcc}
\hline Pemboleh ubah & $\mathrm{r}$ & Sig. \\
\hline Efikasi Kendiri & 0.619 & $0.000^{*}$ \\
Kualiti GPI & & \\
\hline
\end{tabular}

\section{Pengaruh Efikasi Kendiri Terhadap Kualiti GPI SMK}

$\mathrm{H}_{\mathrm{o} 2}$ : Efikasi kendiri tidak memberi pengaruh kepada kualiti GPI SMK

Hipotesis nol kedua $\left(\mathrm{H}_{02}\right)$ yang dibentuk diuji dengan analisis regresi pelbagai stepwise bagi melihat pengaruh relatif empat pemboleh ubah peramal yang berkaitan dengan EK GPI (penglibatan murid, pengurusan bilik darjah, strategi pengajaran, dan bimbingan dan sahsiah) terhadap kualiti sebagai murabbi GPI. Hasil analisis regresi pelbagai stepwise dirumuskan di dalam Jadual 5.

Dapatan analisis regresi pelbagai langkah demi langkah juga menunjukkan bahawa secara signifikan, EK GPI dari aspek strategi pengajaran $(\beta=0.524 ; p<0.05)$ sendiri memberi pengaruh sebanyak $27.5 \%(r=0.524)$ kepada perubahan varians dalam kualiti sebagai murabbi GPI (Model 1). Kombinasi antara kedua-dua pemboleh ubah peramal strategi pengajaran $(\beta=0.387 ; p<0.05)$ dan pengurusan bilik darjah $(\beta=0.243 ; p<0.05)$ pula memberi pengaruh sebanyak $31.5 \%(r=0.561)$ kepada perubahan varians dalam kualiti sebagai murabbi GPI (Model 2). Selain itu, apabila peramal EK GPI dari aspek penglibatan murid $(\beta=0.157 ; p<0.05)$ diambil kira, ketiga-tiga pemboleh ubah peramal tersebut, memberi pengaruh sebanyak $33.1 \%$ $(r=0.585)$ kepada perubahan varians dalam kualiti sebagai murabbi GPI (Model 3). Manakala kombinasi keempat-empat pemboleh ubah peramal EK GPI dari 
aspek strategi pengajaran $(\beta=0.315 ; p<0.05)$, pengurusan bilik darjah $(\beta=0.170$; $p<0.05)$, penglibatan murid $(\beta=0.157 ; p<0.05)$, dan bimbingan akademik dan sahsiah $(\beta=0.109 ; p<0.05)$ pula, secara signifikan memberi pengaruh sebanyak $34.2 \%(r=0.585)$ kepada perubahan varians dalam kualiti sebagai murabbi GPI (Model 4).

Jadual 5. Analisis regresi pelbagai (stepwise) bagi pemboleh ubah peramal berkaitan EK yang mempengaruhi kualiti sebagai murabbi GPI

\begin{tabular}{llcccccc}
\hline Model & Peramal & B & $\begin{array}{c}\text { Ralat } \\
\text { piawai }\end{array}$ & $\beta$ & Sig. & $r$ & $r^{2}$ \\
\hline 1 & Strategi pengajaran & 0.357 & 0.025 & 0.524 & .000 & 0.524 & 0.275 \\
2 & Strategi pengajaran & 0.263 & 0.029 & 0.387 & .000 & 0.561 & 0.315 \\
& Pengurusan bilik darjah & 0.160 & 0.028 & 0.243 & .000 & & \\
3 & Strategi pengajaran & 0.233 & 0.030 & 0.342 & .000 & 0.576 & 0.331 \\
& Pengurusan bilik darjah & 0.117 & 0.030 & 0.178 & .000 & & \\
& Penglibatan murid & 0.104 & 0.029 & 0.161 & .000 & & \\
& Strategi pengajaran & 0.214 & 0.031 & 0.315 & .000 & 0.585 & 0.342 \\
& Pengurusan bilik darjah & 0.112 & 0.030 & 0.170 & .000 & & \\
& Penglibatan murid & 0.102 & 0.028 & 0.157 & .000 & & \\
Bimbingan akademik dan & 0.045 & 0.015 & 0.109 & 0.003 & & \\
& sahsiah & & & & & & \\
& Pemalar (Constant) & 2.292 & .124 & - & .000 & - & \\
\hline
\end{tabular}

Keputusan yang signifikan menunjukkan bahawa keempat-empat model regresi pelbagai yang dibentuk oleh pemboleh ubah bersandar dan pemboleh ubah peramal boleh digeneralisasikan kepada populasinya (Carter, 2004).

\section{PERBINCANGAN}

Kajian ini mendapati bahawa EK GPI di SMK di Semenanjung Malaysia secara puratanya berada pada tahap sangat tinggi, didahului oleh EK dari dimensi penglibatan murid, dan diikuti oleh EK dari dimensi pengurusan bilik darjah, strategi pengajaran dan bimbingan akademik dan sahsiah. Namun, jika diteliti pencapaian skor min mengikut dimensi, dimensi bimbingan akademik dan sahsiah hanya memperoleh skor min tahap tinggi sahaja, yang mana ia merupakan dimensi terendah bagi EK GPI di SMK di semenanjung Malaysia. 
Pada pandangan pengkaji, hal ini tidak sepatutnya berlaku. Ini kerana, pengkaji berpendapat bahawa dimensi bimbingan akademik dan sahsiah merupakan antara misi bagi seseorang GPI, dengan merujuk kepada FPI. Manakala dimensi-dimensi lain seperti penglibatan murid, pengurusan bilik darjah dan strategi pengajaran pula merupakan medium ke arah misi tersebut. Walaupun, EK GPI bagi tiga dimensi tadi sangat tinggi, namun sekiranya EK GPI bagi dimensi yang paling penting, iaitu bimbingan akademik dan sahsiah hanya pada tahap tinggi sahaja, hakikatnya, ia belum mencerminkan tahap EK GPI yang optimum seperti yang diwakili oleh nilai skor min keseluruhan tahap EK GPI iaitu sangat tinggi.

Namun, pengkaji berpandangan hal ini mungkin disebabkan oleh faktor persekitaran GPI seperti faktor beban kerja, murid, sokongan ibu bapa dan komuniti, dan staf sokongan dan kemudahan, yang mana secara tidak langsung mempengaruhi EK GPI khususnya dalam aspek bimbingan akademik dan sahsiah (Bandura, 1997).

Antara andaian lain mengapa EK GPI dalam membimbing akademik dan sahsiah murid tidak setinggi tiga lagi aspek EK adalah kerana, GPI mempunyai persepsi bahawa terdapat beberapa faktor persekitaran sosial yang lain, selain faktor guru yang turut menyumbang kepada pembentukan sahsiah serta penghayatan agama murid. Hal ini dibuktikan dengan dapatan kajian Ab. Halim (2011) yang menunjukkan bahawa pengaruh persekitaran sosial adalah signifikan dalam membentuk sahsiah murid. Hal ini menurut pandangan pengkaji, menjadikan GPI masih belum mencapai tahap keyakinan yang optimum dalam membimbing akademik dan sahsiah murid kerana ia melibatkan banyak faktor lain selain guru, berbanding aspek EK GPI yang lain lebih terfokus kepada kemampuan GPI dalam bilik darjah sahaja seperti penglibatan murid, pengurusan bilik darjah dan strategi pengajaran.

Maka, bolehlah disimpulkan bahawa GPI sangat yakin dengan kemampuan mereka semasa dalam bilik darjah, namun apabila melibatkan skop yang lebih luas, iaitu membimbing akademik dan sahsiah, yang mana bukan sahaja melibatkan kemampuan GPI di dalam bilik darjah, bahkan di luar bilik darjah juga, keyakinan mereka terhadap kemampuan tersebut masih belum mencapai tahap yang optimum.

Jika dilihat kepada amalan terbaik yang boleh dilakukan oleh guru dan dalam konteks kajian GPI dalam membimbing murid seperti yang dinyatakan oleh Zuria (2009), GPI perlulah menjadi rakan kepada murid, pastikan masa yang diluangkan dengan murid terancang, meletakkan jangkaan yang realistik terhadap pencapaian murid, menghargai perubahan positif murid walaupun kecil, mengelakkan rasa kecewa dan putus asa dalam menangani permasalahan murid serta memberikan bimbingan secara ikhlas tanpa menaruh harapan untuk dihargai. 
Walaupun tiada kajian berkaitan EK GPI sebelum ini dijalankan, namun dapatan ini dilihat memberikan kredit yang lebih kepada GPI jika dibuat perbandingan dengan kajian-kajian lepas yang menggunakan instrumen yang sama. Dapatan kajian ini menunjukkan GPI secara keseluruhan memperoleh skor min sangat tinggi, manakala dapatan kajian-kajian yang lain mendapati guru hanya mencapai tahap EK tinggi dan sederhana tinggi. Sebagai contoh, kajian Tengku Lung Kui (2006) berkaitan EK guru yang dijalankan di Kuching dengan melibatkan 420 orang guru daripada 18 buah sekolah menengah mendapati EK guru adalah tinggi. Manakala dapatan kajian Khalid, Zurida, Shuki dan Ahmad Tajuddin (2009) yang memfokuskan kepada guru-guru novis di Sabah, mendapati bahawa tahap EK guru-guru novis di Sabah adalah sederhana tinggi. Manakala pencapaian mengikut dimensi EK, didapati bahawa dimensi pengurusan kelas mendahului, dengan diikuti dimensi strategi pengajaran dan penglibatan murid. Walau bagaimanapun, secara keseluruhan, dapatan ini didapati selari dengan dapatan Rahmah, Mohd Majid, Habibah dan Foo (2006) dan Tschannen-Moran dan Woolfolk Hoy (2002).

Dapatan kajian ini juga ternyata membenarkan andaian pengkaji bahawa EK berkorelasi dengan kualiti GPI SMK di Semenanjung Malaysia. Dapatan ini menyokong dapatan kajian lepas yang mendapati bahawa EK guru mempengaruhi amalan pengajaran guru (Yılmaz \& Çavaş, 2008), pengurusan bilik darjah guru (Giallo \& Little, 2003), personaliti guru (Roberts, Harlin, \& Briers, 2007) dan sifat tidak mudah mengalah apabila berdepan dengan murid yang lemah (Ross, 1995). Manakala ia menyangkal dapatan kajian Barnes (2000) yang mendapati bahawa penurunan EK dalam kalangan guru pelatih tidak menjejaskan kualiti mereka dalam pengajaran.

\section{KESIMPULAN}

Memandangkan kebejatan gejala sosial remaja dewasa ini, pentingnya peranan GPI sebagai murabbi tidak boleh dinafikan. GPI sebagai murabbi berperanan mendidik, membimbing serta mengasuh anak didik dengan penuh kasih sayang bagi mencapai kesempurnaan kendiri yang dizahirkan dalam konsep JERI (Jasmani, Emosi, Rohani dan Intelek) bagi menuju penghujung jalan kehidupan seseorang manusia, iaitu jiwa-jiwa orang tenang. Hal ini seperti yang dinyatakan dalam firman Allah SWT, surah al-Fajr, 89: 27-30. Lantas, GPI sebagai individu yang mendukung serta menyebarkan ilmu Islam sama ada melalui proses pengajaran dan pembelajaran (P\&P), mahupun aktiviti-aktiviti luar, membawa bersama tanggungjawab ini, iaitu membentuk akhlak anak didik mereka. Pada umumnya, kajian ini telah mendapati bahawa kualiti GPI sebagai murabbi berada pada tahap yang sangat tinggi. Namun, jika diteliti kepada setiap dimensi kualiti GPI, tiga 
daripada lapan dimensi hanya memperoleh tahap tinggi, iaitu dimensi pengamalan agama, kemahiran pedagogi dan sumbangan kemasyarakatan. Manakala dimensi yang mencapai tahap sangat tinggi ialah dimensi pemikiran rabbani, penguasaan ilmu agama, budaya keilmuan, kemahiran psikologi, kemahiran komunikasi dan sahsiah. Walaupun secara keseluruhan EK GPI (penglibatan murid, pengurusan bilik darjah dan strategi pengajaran) adalah sangat tinggi dan (bimbingan akademik dan sahsiah) tinggi, namun masih terdapat ruang penambahbaikan. Ini kerana dapatan menunjukkan skor yang diperoleh masih belum mencapai tahap optimum, khususnya aspek bimbingan akademik dan sahsiah. Justeru, GPI perlu mengenal pasti dan mengambil langkah bagi meningkatkan EK.

\section{RUJUKAN}

Ab. Halim Tamuri. (2006). Model Guru Pendidikan Islam: Konsep 5 mim. Paper presented at Seminar Amalan Pengajaran Guru Pendidikan Islam, Faculty of Education, Universiti Kebangsaan Malaysia, 1 April.

Ab. Halim Tamuri. (2011). Penghayatan Islam melalui pengajaran dan pembelajaran. Paper presented at Kongres Pendidikan Islam Kebangsaan, Kementerian Pelajaran Malaysia, Dinasty Hotel Kuala Lumpur, 4-7 December.

Ab. Halim Tamuri. (2012). The role of mosque: The integration approach of teaching and learning process. Paper presented at the International Conference on Research in Islamic and Arabic Languange Education 2012, Elaf Kinda Hotel, Mecca, Saudi Arabia, 1-2 June.

Ab. Halim Tamuri, Adnan Yusopp, Kamisah Osman, Shahrin Awaluddin, Zamri Abdul Rahim, \& Khadijah Abdul Razak. (2004). Keberkesanan kaedah pengajaran dan pembelajaran pendidikan islam ke atas diri pelajar. Research report, Faculty of Education, Universiti Kebangsaan Malaysia, Bangi.

Abdullah Basmeh. (2010). Tafsir pimpinan al-Rahman. Kuala Lumpur: Dar al-Fikr.

Abdullah Md. Din. (2011). Pendidikan Islam Malaysia: Isu dan cabaran. Paper presented at Kongres Pendidikan Islam Kebangsaan 2011, Dinasty Hotel Kuala Lumpur, 4-7 December.

Abdullah Nasih 'Alwan. (1968). Tarbiyyah al-Awlad fi al-Islam. Kaherah: Dar al-Salam. Abu-Tineh M. A., Khasawneh, S. A., \& Khalaileh, H. A. (2011). Teacher self-efficacy and classroom management styles in Jordanian schools. Management in Education, 25(4), 175-181. https://doi.org/10.1177/0892020611420597

Ahmad Kilani Mohamed. (2005). Pengurususan pendidikan di sekolah dari perspektif Islam. Johor: Universiti Teknologi Malaysia.

al-Bayhaqi Ahmad Ibn Husayn. (1988). Al-Sunan al-Kubra. al- Beirut: Majlis Daerah alMa'arif al-Nizamiyyah.

al-Ghazali Abu Hamid. (n.d). Ihya' Ulum Al-Din. Kaherah: al-Masyad.

al-Hafiz Al-Suwaid Muhammad Nur Ibn Abdullah. (1988). Manhaj Tarbiyah Nabawiyyah Li Al-Tifl. Kuwait: Muassasah al-Rayyan. 
al-Hammadi Yusuf. (1987). Al-Tarbiyyah Al-Islamiyyah. Riyad: Dar al-Marikh li al-Nashr. al-Nahlawi Abdul Rahman. (1979). Usul Tarbiyyah Islamiyyah. Beirut: Dar al-Ma'asir.

Alias Baba. (1996). Statistik penyelidikan dan pendidikan dalam sains sosial. Bangi: Universiti Kebangsaan Malaysia.

Ashton, P. (1984). Teacher efficacy: A motivatioanal paradigm for effective teacher education. Journal of Teacher Education, 35(5), 28-32. https://doi. org/10.1177/002248718403500507

Asmawati Suhid. (2005). Pemantapan komponen akhlak dalam Pendidikan Islam bagi menangani era globalisasi. Jurnal Kemanusiaan, 6, 95-104.

Azizi Yahaya, Shahrin Hashim, Jamaludin Ramli, Yusof Boon, \& Abdul Rahim Hamdan. (2006). Menguasai penyelidikan dalam pendidikan. Kuala Lumpur: PTS Professional Publishing Sdn. Bhd.

Bandura, A. (1977). Self-efficacy: Toward a unifying theory of behavioral change. Psychological Review, 84(2), 191-215. https://doi.org/10.1037/0033295X.84.2.191

Bandura, A. (1993). Perceived self-efficacy in cognitive development and functioning. Educational Psychologist, 28(2), 117-148. https://doi.org/10.1207/ s15326985ep2802_3

Bandura, A. (1994). Self-efficacy. In V. R. Ramachaudran (Ed.), Encylopedia of human behavior (pp. 71-81). New York: Academic Press.

Bandura, A. (1997). Self efficacy in changing society. New York: Cambridge University Press.

Barnes, G. V. (2000). Self-eficacy and teaching effectiveness. Journal of String Research, $1,627-643$.

Carter, D. C. (2004). Quantitative psychological research. New York: Psychological Press.

Casey, M. (2011). Perceived efficacy and preparedness of beginning teachers to differentiate instruction. Unpublished doctoral disseration, Faculty of Leadership, Johnson \& Wales University.

Coady, M., Harper, C., \& De Jong, E. (2011). From preservice to practice: Mainstream elementary teacher beliefs of preparation and efficacy with English language learners in the State of Florida. Bilingual Research Journal, 34(2), 223-239. https://doi.org/10.1080/15235882.2011.597823

Cohen, J. W. (1988). Statical power analysis for the behavioral sciences (2nd ed.). Hillsdale, NJ: Lawrence Erlbaum Associates.

Corcoran, T. B. (2007). Teaching matters: How state and local policymakers can improve the quality of teachers and teaching. Philadelphia, PA: Consortium for Policy Research in Education, University of Pennsylvania. https://doi.org/10.12698/ cpre.2007.rb48

Creswell, J. W. (1998). Qualitative inquiry and research design: Choosing among five traditions. New Jersey: Pearson Education.

Darling-Hammond, L., Wei, R. C., Andree, A., Richardson, N., \& Orphanos, S. (2009). Professional learning in the learning profession: A status report on teacher development in the United States and abroad. Washington, DC: National Staff Development Council. 
Donna, T. (2007). A contextual measure of teacher efficacy for teaching primary school students who have ESL. Unpublished doctoral dissertation, Faculty of Education, Queensland University of Technology.

Giallo, R., \& Little, E. (2003). Classroom behaviour problems: The relationship between preparedness, classroom experiences, and self-efficacy in graduate and student teachers. Australian Journal of Educational \& Developmental Psychology, 3, 21-34.

Gibson, S., \& Dembo, M. H. (1984). Teacher efficacy: A construct validation. Jurnal of Educational Psyhology, 76(4), 569-582. https://doi.org/10.1037/00220663.76.4.569

Guilford, J. P., \& Fruchter, B. (1978). Fundamental statistics in psychology and education (6th ed.). Tokyo: McGraw Hill Kogusha Ltd.

Guskey, T. R. (1987). Context variables that affect measures of teacher efficacy. Journal of Education Research, 811(4), 41-52. https://doi.org/10.1080/00220671.1987.1 0885795

Hartman, S. (2010). Teaching American history: The influence of professional development on elementary teacher's self-efficacy and classroom practice. Unpublished doctoral dissertation, University of Nevada, Reno.

Hassan Langgulung. (1986). Pengenalan Tamadun Islam dalam pendidikan. Kuala Lumpur: Dewan Bahasa dan Pustaka.

Hassan Langgulung. (1987). Penghayatan nilai-nilai Islam ditinjau dari proses pembelajaran dalam konteks pendidikan masa kini. Jurnal Pendidikan Islam, 2(5), 13-30.

Henson, R. K., Bennett, D. T., Sienty, S. F., \& Chambers, S. M. (2000). The relationship between means-end task analysis and context specific and global efficacy in emergency certification teachers: Exploring a new model of efficacy. Paper presented at the Annual Meeting of the American Educational Research Association, American Educational Research Association, New Orleans, LA, 24-28 April. https://doi.org/10.3102/0013189X028008033

Henson, R. K., Kogan, L. R., \& Vacha-Haase, T. (2001). A reliability generalization study of the teacher efficacy scale and related instruments. Educational and Psychological Measurement, 61(3), 404-420. https://doi.org/10.1177/00131640121971284

Ishak Sin. (2001). Pengaruh kepimpinan pengajaran, kepimpinan transformasi dan gantian kepada kepimpinan ke atas komitmen terhadap organisasi, efikasi dan kepuasan kerja guru. Unpublished doctoral dissertation, Faculty of Education, Universiti Kebangsaan Malaysia.

Kamarul Azmi Jasmi. (2010). Guru cemerlang Pendidikan Islam sekolah menengah di Malaysia: Satu kajian kes. Unpublished doctoral dissertation, Faculty of Education, Universiti Kebangsaan Malaysia.

Kamarul Azmi Jasmi, \& Ab. Halim Tamuri. (2007). Pendidikan Islam: Kaedah pengajaran dan pembelajaran. Johor: Universiti Teknologi Malaysia.

Khalid Gazali. (2005). Pengaruh efikasi kendiri dan lokus kawalan terhadap komitmen mengajar di kalangan guru-guru kanan teknikal dan vokasional. Unpublished doctoral dissertation, School of Educational Studies, Universiti Sains Malaysia. 
Khalid Johari, Zurida Ismail, Shuki Osman, \& Ahmad Tajuddin Othman. (2009). Pengaruh jenis latihan guru dan pengalaman mengajar terhadap efikasi guru sekolah menengah. Jurnal Pendidikan Malaysia, 34, 3-14.

Khoo, A., \& Tan, S. (2004). Master your mind design your destiny. Singapore: Adam Khoo Learning Publisher.

Larson, L. M., Suzuki, L. A., Gillespie, K. N., Potenza, M. T., Bechtel, M. A., \& Toulouse, A. L. (1992). Counseling self-estimated inventory. Ames, IA: publisher name. https://doi.org/10.1037/t02887-000

Martínez-López, E., Zagalaz Sánchez, M., Ramos Álvarez, M., \& De La Torre Cruz, M. (2010). Self-efficacy expectations in teacher trainees and the perceived role of schools and their physical education department in the educational treatment of overweight students. European Physical Education Review, 16(3), 251-266. https://doi.org/10.1177/1356336X10385044

Mason, J. H. (2010). Exploring the influence of high-stakes testing and accountability on teachers 'professional identities through the factors of instructional practice, work environment, and teacher efficacy. Unpublished doctoral dissertation, Western Carolina University.

Mohd Kamal Hassan. (2011). Pendidikan yang membentuk syakhsiah bangsa dan proses islamisasi. Paper presented at Kongres Pendidikan Islam Kebangsaan 2011, Dynasty Hotel, Kuala Lumpur, 4-7 December.

Mohd Kassim Tusin. (2010). Kualiti guru Pendidikan Islam sekolah menengah di Sabah. Unpublished doctoral dissertation, Universiti Malaysia Sabah.

Neuman, W. L. (2002). Social research methods: Quantitative and qualitative approaches (5th ed.). Needham Height, MA: Allyn and Bacon.

Noornajihan Jaafar, \& Ab. Halim Tamuri. (2012). Guru Pendidikan Islam sebagai murabbi: Satu keperluan dalam mendepani remaja Islam abad-21. Prosiding Seminar Antarabangsa Perguruan dan Pendidikan Islam 2012, 239-248.

Noornajihan Jaafar, Nurul Asiah Fasehah, Ab. Halim Tamuri, Azhar Ahmad, Nur Hanani Hussin, Mohd Kamal Md. Daud, \& Maziahtusima Ishak. (2019). The significant correlation between self efficacy and the role of Islamic education teachers as a society change agent. Mediterranean Journal of Social Sciences, 10(3), 83. https://doi.org/10.2478/mjss-2019-0044

Pas, E. T., Bradshaw, C. P., \& Hershfeldt, P. A. (2011). Teacher-and school-level predictors of teacher efficacy and burnout: Identifying potential areas for support. Journal of School Psychology, 50(1), 129-145. https://doi.org/10.1016/j.jsp.2011.07.003

Rafisah Osman. (2009). Hubungan kualiti penyeliaan pengajaran dan pembelajaran dengan komitmen dan efikasi guru. Unpublished doctoral dissertation, Faculty of Education, Universiti Utara Malaysia.

Rahmah Murshidi. (2005). Factors associated with sense of efficacy among first year teachers in Sarawak. Unpublished doctoral dissertation, Universiti Putra Malaysia.

Rahmah Murshidi, Mohd Majid Konting, Habibah Elias, \& Foo, S. F. (2006). Sense of efficacy among beginning teachers in Sarawak. Teaching Education, 17(3), 265275. https://doi.org/10.1080/10476210600849730 
Rimm-Kaufman, S. E., \& Sawyer, B. E. (2004). Primary-grade teachers' self-efficacy beliefs, attitudes toward teaching, and discipline and teaching practice priorities in relation to the "responsive classroom" approach. The Elementary School Journal, 104(4), 321-341. https://doi.org/10.1086/499756

Roberts, T. G., Harlin, J. F., \& Briers, G. E. (2007). The relationship between teaching efficacy and personality type of cooperating teachers. Journal of Agricultural Education, 48, 55-66. https://doi.org/10.5032/jae.2007.04055

Rorlinda Yusof. (2009). Kecerdasan emosi, efikasi kendiri dan sumbangan terhadap komitmen guru kaunseling sekolah menengah. Unpublished doctoral dissertation, Faculty of Education, Universiti Kebangsaan Malaysia.

Ross, J. A. (1995). Strategies for enhancing teacher's belief in their effectiveness: Research on a school improvement hypothesis. Teacher College Record, 97(2), 227-251.

Ruhi Ba'albaki. (2004). Al-Mawrid. Beirut: Dar al-'Ilm li Maliyin.

Saaidah Abdul Rahman. (2005). Pengaruh iklim sosial dan iklim tugasan terhadap sikap kerja guru-guru, pencapaian pelajar dan keberkesanan sekolah. Unpublished doctoral dissertation, Faculty of Education, Universiti Kebangsaan Malaysia.

Saklofske, D. H., Michayluk, J. O., \& Rondhawa, B. S. (1988). Teacher's efficacy and teacher behaviours. Psychological Reports, 63(2), 407-414. https://doi. org/10.2466/pr0.1988.63.2.407

Sazali Yusoff. (2004). Pengaruh efikasi-kendiri dan kecerdasan emosi guru besar terhadap efikasi kolektif guru dan iklim organisasi sekolah. Unpublished doctoral dissertation, School of Distance Education, Universiti Sains Malaysia.

Settlage, J., Southerland, S. A., Smith, L. K., \& Ceglie, R. (2009). Constructing a doubtfree teaching self: self-efficacy, teacher identity, and science instruction within diverse settings. Journal of Research in Science Teaching, 46(1), 102-125. https://doi.org/10.1002/tea.20268

Steele, N. A. (2010). Three characteristics of effective teachers. Update: Applications of Research in Music Education, 28(2), 71-78. https://doi. org/10.1177/8755123310361769

Sofiah Mohamed, Kamarul Azmi Jasmi, \& Muhammad Azhar Zailaini. (2016). Akhlak guru dalam pengajaran dan pembelajaran Pendidikan Islam. Akademika, 86(2), 31-42. https://doi.org/10.17576/akad-2016-8602-02

Tengku Lung Kui. (2006). Pengaruh faktor terpilih terhadap efikasi kendiri guru di sekolah menengah di negeri Sarawak. Unpublished doctoral dissertation, Universiti Putra Malaysia.

Trentham, L., Silvern, S., \& Brogdon, R. (1985). Teacher efficacy and teacher competency ratings. Psychology in the Schools, 22(3), 343-352. https://doi.org/10.1002/15206807(198507)22:3\%3C343::AID-PITS2310220317\%3E3.0.CO;2-0

Tschannen-Moran, M., Hoy, A. W., \& Hoy, W. K. (1998). Teacher efficacy: Its meaning and measure. Review of Educational Research, 68(2), 202-248. https://doi. org/10.3102/00346543068002202

Weisel, A., \& Dror, O. (2006). School climate, sense of efficacy and israeli teachers' attitudes toward inclusion of students with special needs. Education, Citizenship and Social Justice, 1(2), 157-174. https://doi.org/10.1177/1746197906064677 
Yahya Don, Azah Ismail, \& Yaakub Daud. (2006). Pembangunan dan kepimpinan pelajar sekolah di Malaysia. Kuala Lumpur: PTS Professional Publishing Sdn. Bhd.

Yılmaz, H., \& Çavaş, P. (2008). The effect of the teaching practice on pre-service elementary teachers' science teaching efficacy and classroom management beliefs. Eurasia Journal of Mathematics, Science \& Technology Education, 4(1), 45-54. https:// doi.org/10.12973/ejmste/75305

Yoon, S. J. (2002). Teacher characteristics as predictors of teacher-student relationships: Stress, negative affect, and self-efficacy. Social Behavior and Personality: An International Journal, 30(5), 485-493. https://doi.org/10.2224/sbp.2002.30.5.485

Zuria Mahmud. (2009). Profesion perguruan: Cabaran pendidikan masa kini. Bangi: Fakulti Pendidikan, Universiti Kebangsaan Malaysia. 